\title{
SOCIO-EMOCIONALNI PROBLEMI I PROBLEMI U PONAŠANJU DECE PREDŠKOLSKOG UZRASTA I MOGUĆNOSTI INTERVENCIJE**
}

Apstrakt: Broj dece koja imaju socijalne i emocionalne poteškoće konstantno raste. Socio-emocionalni problemi i problemi u ponašanju mogu predstavljati rizik za pojavu ozbiljnijih poremećaja u kasnijem životu. Pored toga, deca sa problemima u ponašanju i nedovoljno razvijenim socio-emocionalnim kompetencijama imaju tendenciju da se teže uključuju u vršnjačku interakciju, a ponekad su čak isključena iz socijalnih aktivnosti. Mnoga deca sa osnovnim socio-emocionalnim problemima i problemima u ponašanju kojima nedostaje formalna dijagnoza, kao što su npr. poremećaji autističnog spektra, ne dobijaju nužno nikakvu pomoć ili intervenciju, dok istovremeno predstavljaju izazov sa kojim ni roditelji ni vaspitači ne mogu da se nose. Deca su tako izložena riziku i zbog toga se čini neophodnim istražiti i razumeti koje su moguće intervencije za podršku socijalnom i emocionalnom razvoju dece predškolskog uzrasta. Intervencija na predškolskom uzrastu može biti usmerena na roditelje kroz različite programe podrške, edukacijem kao i na decu putem obuke, u vidu različitih oblika intervencija zasnovanih na igri; ali, istovremeno i na roditelje $\mathrm{i}$ na decu.

Ključne reči: intervencija, dete, socio-emocionalni problemi, problemi u ponašanju.

\section{UVOD}

Socijalno-emocionalni razvoj smatra se jednim od najvažnijih aspekata razvoja deteta $\mathrm{i}$ njegove dobrobiti. Osim toga, zdrav socijalni i

\footnotetext{
*Aleksandra Pavlović, aleksandrapavlovic6@gmail.com

** Rad je nastao u okviru projekta Pedagoški pluralizam kao osnova strategije obrazovanja (179036) koji finansira Ministarstvo prosvete, nauke i tehnološkog razvoja.
} 
emocionalni razvoj olakšava angažovanje i učešće deteta u društvenim interakcijama. Ovaj društveni angažman zauzvrat ima pozitivan uticaj na socijalno-emocionalni razvoj. Ukoliko deca ne vladaju veštinama $u$ socijalnim ili emocionalnim područjima, preti im opasnost da budu isključena i odbačena od strane vršnjaka, što može dovesti do negativnih ishoda po mentalni i psihički razvoj.

Najoptimalnije doba za poboljšanje sposobnosti povezanih sa socijalnim i emocionalnim razvojem je predškolski uzrast (Kariuki, Chepchieng, Mbugua, \& Ngumi, 2007). Razlog za to može biti taj što deca u tom uzrastu provode dosta vremena u predškolskoj ustanovi gde se povezuju sa vršnjacima. U predškolskoj ustanovi deca uče veštine vršnjačke interakcije i kako biti saglasan sa drugima. Istraživanja pokazuju da deca koja odrastaju i žive u rizičnim sredinama, kao i deca sa smetnjama u razvoju, imaju veću verovatnoću da će ispoljiti probleme u ponašanju (Baker, Blacher, \& Olsson, 2003). Socijalne i emocionalne kompetencije mogu smanjiti eksternalizovana problemska ponašanja i tako pozitivno uticati na detetov razvoj. Takođe, socio-emocionalni razvoj uglavnom se smatra prekretnicom i važnim aspektom spremnosti za školu (Schmitt, Flay, \& Lewis, 2014).

Emocionalni razvoj uključuje sposobnost upravljanja i regulaciju emocija, prepoznavanja sopstvenih emocija i emocija drugih. On takođe podrazumeva sposobnost da se na odgovarajući način izraze sopstveni osećaji, kao i sposobnost usklađivanja sa svakodnevnim životnim situacijama i izazovima (Ashiabi, 2007). Emocionalno blagostanje ima veliki uticaj na društveni razvoj (Caselman, \& Self, 2008). Ukoliko deca imaju problema u emocionalnom razvoju, ona će najverovatnije imati i problema u socijalnom, 
i to je jedan od razloga zašto se neusklađen emocionalni razvoj i problemi $u$ ponašanju uglavnom pominju zajedno.

Jedan od najvažnijih uticaja na pozitivan razvoj emocija ima okruženje u kojem dete odrasta, uči, igra se i živi. Ako je okruženje neprikladno ili neosetljivo na potrebe deteta, ili zasićeno različitim faktorima rizika (npr. dugotrajno odsustvo detetu važne odrasle osobe, nasilno rešavanje problema, ekstremno siromaštvo), dete će najverovatnije imati poteškoća da razvije korisne i relevantne emocionalne kompetencije. Istraživanja pokazuju da nedostatak emocionalnih kompetencija, ili, preciznije, nedostatak emocionalne regulacije i uočavanja emocija, u detinjstvu često izaziva agresivno ponašanje ili eksternalizovane teškoće uopšte, kao što su poremećaj ponašanja i antisocijalno ponašanje (Denham et al., 2003).

Iz tog razloga, neophodno je baviti se osnaživanjem i razvojem socioemocionalnih kompetencija dece već od ranog uzrasta, ali i rešavanjem problema u ponašanju. Postoje različiti pristupi i polazišta u oblikovanju intervencija. Jedan od kriterijuma njihovog razlikovanja je ciljna grupi na koju su usmerene. S obzirom na to, razlikujemo intervencije usmerene na dete, intervencije usmerene na roditelje i one koje su usmerene na decu i roditelje istovremeno.

\section{SOCIO-EMOCIONALNI PROBLEMI I PROBLEMI U PONAŠANJU DECE PREDŠKOLSKOG UZRASTA}

Veliki broj dece od rođenja do pete godine iskusi socio-emocionalne probleme i probleme u ponašanju zbog različitih rizičnih faktora u vezi sa njima samima, sredinom i/ili porodicom (Bratton, Ray, Rhine, Jones, 2005). 
Međutim, iz različitih razloga teško je identifikovati socijalne i emocionalne probleme dece predškolskog uzrasta. Ipak, razvijeno je mnogo pristupa proceni kako bi se podržala identifikacija emocionalnih problema i problema u ponašanju (Caselman, \& Self, 2008).

Iako je postignut veliki napredak u identifikaciji i sprovođenju intervencija emocionalnih problema $u$ ponašanju, broj dece sa ovim problemima i dalje raste (Carter, Briggs-Gowan, \& Davis, 2004). Da bi se razumelo u kojoj meri oni utiču na socijalni i emocionalni razvoj deteta i da bi se omogućilo efikasno dalje istraživanje, važno je znati kako se emocionalne i bihevioralne poteškoće definišu. Ranije, emocionalni problemi i problemi u ponašanju definisani su kao devijantno ponašanje, naročito kada je reč o ranom detinjstvu. Deca koja su se ponašala neprilagođeno (neadekvatno) ili u bilo kojem smislu drugačije od druge dece pripadala bi ovoj kategoriji. Danas, u emocionalne teškoće i teškoće u ponašanju spada više supkategorija iako je za svu decu koja ispoljavaju neki oblik takvog ponašanja uglavnom karakteristično da nemaju dovoljno razvijene socijalne i emocionalne kompetencije.

Pored toga, istraživanja pokazuju da socio-emocionalni problemi i problemi u ponašanju u ranim godinama imaju tendenciju rasta ukoliko se ne sprovodi neka intervencija (Carter et al., 2004). Zbog ovih nalaza, važno je spomenuti da se problematična ponašanja u kasnijim godinama ne događaju neočekivano ili iznenada. S obzirom da socio-emocionalne i bihevioralne poteškoće imaju svoje poreklo već u ranom detinjstvu, uglavnom $\mathrm{u}$ predškolskom uzrastu, veoma je važno da intervencije već postoje i da se odvijaju u tim godinama. Drugi razlog za ranu intervenciju socijalnoemocionalnog razvoja dece jeste da deca u ovom uzrastu obično još uvek 
nisu u stanju da sami menjaju svoje ponašanje (Waliski \& Carlson, 2008). Kroz ciljane intervencije oni su u mogućnosti da dobiju podršku koja im može pomoći da promene svoje ponašanje.

Neka deca doživljavaju teže oblike socio-emocionalnih teškoća i teškoća u ponašanju nego druga deca. To znači da neka deca, na primer, samo pokazuju simptome takvih teškoća, dok druga deca imaju dijagnostifikovane socio-emocionalne poteškoće kao što su ADHD ili poremećaj autističnog spektra. Naravno, razlike između simptoma i dijagnostičkih teškoća moraju biti poznate kada se planiraju intervencije.

Socio-emocionalne i bihevioralne poteškoće mogu se podeliti na internalizovane i eksternalizovane probleme u ponašanju (Jianhong, 2004). Eksternalizovana ponašanju su najčešći i najuočljiviji oblici emocionalnih teškoća i problema u ponašanju. Deca koja ispoljavaju eksternalizovane probleme u ponašanju predstavljaju veliki izazov za osobe u svom okruženju. Ovakva ponašanja uglavnom su povezana sa emocionalnom regulacijom i obično su, ukoliko ne postoji adekvatna podrška, istrajna. Istaživanja su pokazala da postoje polne razlike kada je reč o eksternalizovanim problemima u ponašanju. Prema njima, dečaci su skloniji ovim oblicima ponašanja (Žunić-Pavlović i Kovačević-Lepojević, 2011). Neki od eksternalizovanih problema u ponašanju su poremećaj pažnje, pormećaj ponašanja, agresivno ponašanje i antisocijalno ponašanje (Jianhong, 2004).

Deca sa poremećajem pažnje imaju poteškoća da istraju u jednoj specifičnoj situaciji duži vremenski period. Za ovu decu je izazov biti skoncentrisan i biti deo grupnih (zajedničkih) aktivnosti. Istraživanja pokazuju da oko deset posto predškolske dece ima poremećaj pažnje. 
Dokazano je da poremećaj pažnje ima jak negativan uticaj na socioemocionalno ponašanje. Takođe, poremećaj pažnje ima dugoročne posledice kao što jr antisocijalno ponašanje (Campbell, Shaw, \& Gilliom, 2000). Iz tih razloga važno je da se deci koja ispoljavaju ovakvo ponašanje pruži individualna i adekvatna intervencija, $\mathrm{i}$ to što ranije.

Uključujući agresivno delanje, poremećaj ponašanja je deo emocionalne uzmenirenosti. Deca koja redovno ispoljavaju neadekvatno ponašanje svakodnevno - kao što su udaranje, guranje, vikanje ili uznemirujuće reči - povezuju se sa poremećajima u ponašanju ili agresivnim ponašanjem. Istraživanja su pokazala da su deca koja ispoljavaju agresivno ponašanje gotovo uvek odbačena od strane vršnjaka koji se plaše njihovih reakcija (Dodge et al., 2003; Ladd, 2006). Isključenost od strane vršnjaka ima negativan ishod na eskalaciju problema, s obzirom da postoji tendencija ispoljavanja više simptoma ovakvog ponašanja. Takođe, istraživanja su pokazala i vezu između agresivnog i antisocijalnog ponašanja (ŽunićPavlović i Kovačević-Lepojević, 2011).

Antisocijalno ponašanje usko je povezano sa socijalnim razvojem i proizlazi iz nedovoljno razvijenih socijalnih veština i empatije, koju prouzrokuju različiti faktori uglavnom povezani aa porodicom (Diken, \& Rutherford, 2005).

Kada govorimo o faktorima koji utiču na razvoj ovakvih oblika ponašanja, treba imati na umu da sve vrste ekoloških faktora mogu uticati na razvoj deteta i stoga se mogu pretvoriti u faktore rizika. Veliki faktor rizika za socio-emocionalno blagostanje dece jeste siromaštvo. Deca koja žive u porodicama sa niskim primanjima više su podložna problemima u ponašanju nego druga deca (Sjöman, Granlund, \& Almqvist, 2016). Porodična sredina 
u kojoj dete odrasta ima veliki uticaj na razvoj deteta i obuhvata nivo obrazovanja roditelja i njihovo psihičko zdravlje. Ako roditelji imaju nizak obrazovni status ili određene psihičke probleme, veća je verovatnoća da će biti nezaposleni, što rezultira niskim primanjima i može uticati na zdrav razvoj deteta i predstavljati izvor stresa na relaciji roditelj - dete (Classens, 2012).

\section{INTERVENCIJE USMERENE NA RODITELJE}

Postoji mnogo dokaza da rano početno problematično ponašanje dovodi decu u opasnost od ozbiljnih poremećaja u ponašanju, hroničnog antisocijalnog ponašanja i upotrebe droga. Razvojne studije ranog detinjstvu sugerišu da porodični, dečji i društveni faktori igraju značajnu ulogu u nastanku ovih problema. Od potencijalnih uzročnih faktora, veština roditeljstva je posebno značajna (Gardner, Dishion, Shaw, \& Burton, 2007).

Programi usmereni na roditelje obično su kategorizovani tako da uključuju „podršku porodici“, „obrazovanje roditelja“ i „obuku roditelja“. Ponekad se ovi termini koriste kao sinonimi. Međutim, oni se ne preklapaju uvek. Na primer, programi podrške ne uključuju samo usluge koje pomažu roditeljima u njihovoj ulozi, već mogu uključivati i druge usluge kao što su obuka za posao ili opismenjavanje odraslih, dok programi edukacije roditelja mogu podrazumevati samo usluge obrazovanja roditelja (Unicef, 2014).

Podrška roditeljima dolazi iz različitih izvora, često široko grupisanih u neformalnu (porodica, prijatelji i komšije, koji proizilaze iz sopstvenih „prirodnih“ mreža), poluformalnu (organizacije u zajednici, uglavnom od strane dobrovoljnog sektora) i formalnu podršku (organizovane usluge često zasnivane na potrebama, a obezbeđuje ih samo vladin sektor ili u partnerstvu 
sa nevladinim sektorom). Razvojni fokus programa odnosi se na činjenicu da se roditeljski programi mogu fokusirati na različite razvojne domene dece i na faze od prenatalnog perioda do predškolskog uzrasta i polaska u školu (mogu se razlikovati u cilju razvoja roditelja, od specifičnih roditeljskih veština, preko veština poučavanja, do izgradnje odnosa ili čak osnaživanja). Namera autora nekih programa je poboljšanje roditeljskih znanja i veština $u$ vezi sa negom, ishranom i zdravljem deteta, dok se drugi fokusiraju na rano obrazovanje i učenje. Postoje i programi koji su usredsređeni na smanjenje surovog roditeljstva i nasilja u porodici. Neki se fokusiraju na roditelje sa decom od rođenja do treće godine, dok su drugi namenjeni roditeljima dece od tri godine i više. Tipično, programi koji se fokusiraju na mlađe uzrasne grupe usmereni su na zdravlje, ishranu i/ili stimulaciju, dok su oni namenjeni nešto starijoj deci usmereni na socijalni razvoj, učenje i obrazovanje (Unicef, 2014).

Iako se mnogi preventivni programi u ranom detinjstvu zasnivaju na aspektima roditeljstva, postoje i oni koji uključuju i druge faktore rizika u vezi sa porodicom i decom faktore koji, takođe, utiču na probleme $\mathrm{u}$ ponašanju. Posebno relevantni za porodice koje žive u siromaštvu su faktori koji hronično podrivaju pokušaje roditelja da obezbede dovoljne ekonomske i emocionalne resurse za njihovu decu. Tako, porodični faktori kao što su blagostanje roditelja, osećaj zadovoljstva u pogledu socijalne podrške unutar i izvan porodice i tipične roditeljske muke - uobičajena je korelacija života $u$ siromaštvu povezana sa problemima ponašanja $u$ ranom detinjstvu. Osim toga, porodice koje žive u siromaštvu obično se bore sa pitanjima kao što su obezbeđivanje pristupačne brige o deci, predškolske ustanove, adekvatna ishrana i sigurni smeštaj. Ovo zapravo znači da siromaštvo i nepovoljna 
socioekonomska situacija ne vode sami po sebi do problema u ponašanju dece, ali da utiču na roditelje koji, izloženi stresu i nizu negativnih okolnosti, često ne uspevaju da se usredsrede na emocionalne potrebe dece i aktivnosti koje su od značaja za njihov razvoj (Klemenović, 2014).

Takođe, istraživanja intervencije sugerišu da postoji povezanost depresije majke i psihopatologije kod dece. Majke kojima je dijagnostikovan poremećaj depresije - koje su imale decu sa internalizovanim problemima $u$ ponašanju - podvrgnute su interpersonalnoj psihoterapiji. Terapija za majku bila je povezana sa poboljšanjima u internalizovanom problematičnom ponašanju dece školskog uzrasta i adolescenata. Ponašanje dece poboljšalo se nakon tri do šest meseci bez obzira da li su istovremeno i sama deca/adolescenti imali neke tretmane (Shaw, \& Taraban, 2018).

Brojne intervencije fokusirane su na poboljšanje znanja, stavova i veština roditelja dece sa eksternalizovanim ponašanjem. U većini slučajeva delotvorne intervencije dizajnirane su da roditeljima ukažu na veštine koje će im pomoći da usmere ponašanje njihove dece u pozitivnom smeru.

Jedna od najčešće korišćenih međunarodnih intervencija za pomoć roditeljima u prevenciji i menjanju izazovnog ponašanja njihove dece je Triple P (Positive Parenting Program), sistem podrške koji obezbeđuje sve intenzivnije intervencije zasnovane na potrebama roditelja $i$ dece. Intervencije se kreću od osnovnih informacija o roditeljstvu na najmanje intenzivnom nivou, do upravljanja ponašanjem. Triple $P$ je dizajniran da spreči i tretira socijalne, emocionalne i probleme u ponašanju dece usvajanjem znanja, veština i poverenja roditelja u njihovu roditeljsku ulogu. Triple $P$ je oblik intervencije zasnovan na principima socijalnog učenja. Ovaj 
pristup lečenju i prevenciji ima empirijsku podršku, posebno kada se govori o prevenciji problema u ponašanju. Triple $P$ ima za cilj da poboljša porodične zaštitne faktore i smanji faktore rizika povezane sa ponašanjem i emocionalnim problemima dece i adolescenata. Konkretno, program ima za cilj da: unapredi znanje, veštine, poverenje i snalažljivost roditelja; promoviše negujuće, sigurno, privlačno, nenasilno i nisko konfliktno okruženje za decu; promoviše socijalne, emocionalne, jezičke, intelektualne sposobnosti, kao i kompetencije dečijeg ponašanja kroz pozitivnu roditeljsku praksu (Sanders, Markie-Dadds, Tully, \& Bor, 2000).

Kako bi se utvrdili efekti ovog programa, nakon šest i dvanaest meseci izvršena je analiza prethodnih istraživanja evaluacije preventivnih intervencija usmerenih na roditelje, a koje primenjuju nivo 4 Triple $P$ sistema koji se odnosi na intenzivan program obuke roditelja dece sa težim teškoćama u ponašanju ili koja su izložena riziku da razviju takve probleme. Ovaj nivo intervencije osmišljen je kao javnozdravstvena strategija za promovisanje boljeg roditeljstva. Rezultati pokazuju da su intervencije koristeći nivo 4 Triple $P$ sistema poboljšale ponašanje deteta, što primećuju i roditelji. Poboljšanje $u$ dečjem ponašanju se tokom vremena održava i čini se da se donekle i dugoročno poboljšava. Uspeh intervencija u različitim zemljama posledica je uključivanja i prevencije univerzalnih uzoraka visokog rizika. Takođe, ovi rezultati podržavaju sve šire usvajanje i implementaciju ovog programa u prilično različitim kulturnim kontekstima širom sveta (de Graaf, Speetjens, Smit, de Wolff, \& Tavecchino, 2008).

Triple $P$ se primenjuje u više od 20 zemalja, uključujući SAD, Kanadu, Australiju, Belgiju, Japan, Iran, Singapur, Holandiju, Englesku, Nemačku, Švajcarsku, Francusku i Švedsku. Takođe je razvijen i niz 
specijalnih Triple $P$ programa, kao što su Stepping Stones Triple $P$ (za roditelje dece sa smetnjama u razvoju), Family Transitions Triple $P$ (za roditelje koji prolaze kroz razvod) i Lifestyle Triple $P$ (prevencija gojaznosti kod dece) (Özyurt, Dinsever, Çaliskan, \& Evgin, 2018).

\section{INTERVENCIJE USMERENE NA DETE ZASNOVANE NA IGRI}

Kada govorimo o igri kao prevenciji socio-emocionalnih problema i problema u ponašanju, važno je razlikovanje igre kao dobrovoljne i relaksirajuće aktivnosti $\mathrm{i}$ igre koja se primenjuje $\mathrm{u}$ terapiji dece. Igra $\mathrm{u}$ svakodnevnom životu za dete predstavlja najprirodniji način na koji ono uči o sebi, drugima i svetu koji ga okružuje. Igra u terapiji primenjuje se od strane edukovane osobe, u terapijkoj sobi za igru i ima za cilj pomoć detetu da izrazi svoja osećanja, brige i strahove, poboljša samopoštovanje i razvije strategije rešavanja problema (Tahirović, 2015). Zapravo, i igra, ali i terapijski pristupi zasnovani na igri, mogu biti polazište pristupima usmerenim na razvoj socio-emocionalnih kompetencija i prevenciji i suzbijanju problema u ponašanju.

Uopšte, dečija igra je konceptualizovana u terminima kreativnosti, adaptacije, istraživanja, eksperimentisanja, učenja, komunikacije, socijalizacije i akulturacije. Iz socio-konstruktivističke perspektive, igra deci pruža obogaćivanje znanja, iskustva i veština kroz interakciju sa okruženjem, drugima i samim sobom. Takođe, igra je najpogodniji način na koji deca mogu da uče, ona olakšava rešavanje problema, razvija socijalne i emocionalne veštine (Ashiabi, 2007).

Neke od socijalnih koristi igre su razvijanje empatije, saosećanja, pružanje mogućnosti izbora, razvoj neverbalnih veština, pažnje i istrajnosti 
(Goldstein, 2012). Sa godinama, deca često učestvuju u kooperativnoj igri sa dvoje ili više dece, sa dodeljenim ulogama i zajedničkim ciljem. Socijalnodramska igra ili igra pretvaranja je kooperativna igra i čini oko dve trećine svih glumačkih igara predškolske deca. Istraživanje podržava socijalnodramsku igru kao sredstvo za razvoj dečijih socio-emocionalnih veština jer zahteva refleksiju, empatiju, emocionalno razumevanje i regulaciju. Igra pretvaranja pruža deci mogućnost vežbanja sagledavanja perspektive drugih. Igra pretvaranja povezuje se sa detetovim razumevanjem emocija drugih i sa visokom emocionalnom regulacijom i kompetencijom. Takođe, tzv. "grublje igre” pružaju deci mogućnost da vežbaju izražavanje emocija, da kod drugih razlikuju prave emocije od emocija koje igraju. Takođe, Pešikan i Antić (2012) navode da su igre uloga i socijalno dramske igre od ključnog značaja za socijalni razvoj deteta, jer kroz njih deca usvajaju različite uloge, pravila i obrasce ponašanja u društvu.

Neke od emocionalnih prednosti igre su: smanjivanje straha, anksioznosti, stresa, razdražljivosti; pružanje radosti, intimnosti, samopoštovanja; razvoj emocionalne fleksibilnosti i otvorenosti; povećavanje smirenosti, otpornosti i sposobnosti prilagođavanja promenama (Goldstein, 2012). Dok se igraju, deca uče da kontrolišu svoje emocije. Uče kako da istraju u nekoj aktivnosti, da se suoče sa problemom i da ga rešavaju. Uče šta je dobro a šta loše, kako da slede uputstva razvijajanja svoje mašte. Naročito kroz crtanje, bojenje i muziku, imaju mogućnost da izraze sebe. Kroz te aktivnosti mogu iskazati svoja osećanja, kako ona pozitivna, tako i bes, tugu ili gnev. Kroz kreativnu igru mogu izraziti i strahovi i nade, želje. Kad ohrabrujemo decu da izraze svoju maštu i kretivnost, bilo kroz crtanje, izmišljanje priča, pokrete ili slično, ohrabrujemo ih da čuvaju svoje snove $\mathrm{i}$ 
nade, da razvijaju samopouzadnje i sigurnost.Veoma je važno u igri prihvatiti inicijativu deteta, jer tako ono razvija sopstvene ideje, uči da rešava probleme i koristi odgovarajući jezik (Pešikan i Antić, 2012).

Igra sa vršnjacima podstiče društveno razumevanje i odnose. Kako deca razvijaju odnose i nailaze na probleme, proširuju svoje veštine otkrivanja strategija koje deluju i one koje ne deluju, uče kako održati odnose i kako rešiti probleme. Takođe, pretvaranje je rani indikator sposobnosti dece da uoče stanje drugih. Deca obično ne mogu da otkriju nameru drugih pre četvrte godine, ali se upuštaju u igru pretvaranja (koja zahteva shvatanje namera drugih) od oko 18 meseci. Dakle, izgleda da deca prvo kroz igru počinju da razumeju razliku između pretvaranja i stvarnosti a možda i namera drugih (Bailey, 2002).

Kako bi se sprečili problemi u vezi sa mentalnim zdravljem u ranom detinjstvu, važno je sprovesti intervencije koje se ne fokusiraju samo na smanjenje problema sa eksternalizovanim oblicima ponašanja. Ove intervencije, takođe, treba da imaju za cilj izgradnju socijalnih i emocionalnih veština koje su faktori podrške za mentalni razvoj deteta (Schmitt et al., 2014). Intervencije mogu da implementiraju različiti stručnjaci. Imajući u vidu predškolsko okruženje, intervencije mogu sprovesti profesionalci kao što su specijalni edukatori, psiholozi ili pedagozi, ali i vaspitači koji imaju mogućnost vođenja intervencija u grupama ili individualno.

Intervencije igranja uglavnom su podržavajući pristupi koji uključuju bilo koji vid igre, što znači - stvarajući atmosferu koju deca doživljavaju kao razigranu. Ove situacije treba da stimulišu slobodu deteta da istražuje i 
isprobava stvari. Intenzitet pristupa zasnovanog na igri je da se deci pruži osećaj igre umesto učenja.

Najpoznatiji pristup intervencije zasnovane na igri je formalizovana Terapija igrom (Play Therapy). Terapija igrom uglavnom se sprovodi na deci sa problemima mentalnog zdravlja i stoga je prikladna za decu sa socioemocionalnim problemima (Bratton, Ray, Rhine, \& Jones, 2005). Pošto ne postoji univerzalna definicija igre uopšte, teško je pronaći i definiciju za terapiju igrom (VanFleet, Sywulak, \& Caparosa-Sniscak, 2010). Terapija igrom može se opisati kao efikasna terapija koja pomaže deci u promeni ponašanja, razjašnjavanju njihovog self koncepta i izgradnji zdravih odnosa. $\mathrm{U}$ terapiji igrom deca ulaze $\mathrm{u}$ dinamičan odnos sa terapeutom koji omogućava izražavanje, istraživanje i razumevanje njihovog teškog i bolnog iskustva. Terapija igrom pomaže deci da pronađu zdravije načine komuniciranja, grade bogatije odnose, razvijaju rezilijentnost i olakšavaju emocionalnu pismenost (Ray, 2004).

Terapija igrom je psihoterapijski pristup koji se prvenstveno koristi kako bi se pomoglo deci od tri do dvanaest godina da istražuju svoj život i slobodno izražavaju potisnute misli i emocije kroz igru. Terapeutska igra se obično odvija u bezbednoj, udobnoj igraonici, gde se detetu ne nameću brojna pravila i ograničenja ohrabrujući slobodno izražavanje i omogućavajući terapeutu da posmatra detetove izbore, odluke i stil igre. Cilj je da se pomogne deci da nauče da se izražavaju zdravijim načinima, razviju više poštovanja i saosećanja i da otkriju nove i pozitivnije načine rešavanja problema. Terapija igrom pomaže deci sa socijalnim ili emocionalnim problemima da nauče da bolje komuniciraju, menjaju svoje ponašanje, razvijaju veštine rešavanja problema i odnose prema drugima na pozitivan 
način. Pogodan je za decu koja prolaze krizu ili su svedoci stresnih događaja u svom životu, kao što su ozbiljna bolest ili hospitalizacija, nasilje u porodici, zlostavljanje, trauma, porodična kriza ili bilo koja uznemirujuća promena u njihovom okruženju. Terapija igrom može pomoći deci sa akademskim i socijalnim problemima, poteškoćama u učenju, poremećajima u ponašanju, anksioznosti, depresiji, tugi ili ljutnji, kao i poremećajima deficita pažnje (Bratton et al., 2005).

Terapija igrom je dobro poznat i implementiran pristup i postoji mnogo različitih tipova terapije igrom u zavisnosti od poteškoća i potrebe deteta (VanFleet et al., 2010). Uzimajući u obzir postojeću literaturu, očigledno je da je terapija igrom najčešće primenjen pristup orijentisan na igru. Terapija igrom je tehnika tokom koje se detetu pruža prilika da iskusi razvoj pod idealnim okolnostima. Igranje je prirodan način da se deca izraze i obezbeđuje mogućnost postepenog oslobađanja potisnutih emocija i tenzije, razočaranja, osećaja nesigurnosti, agresije i straha od konfuzije.

Preventivne intervencije zasnovane na igri moguće je i poželjno sprovoditi u predškolskim ustanovama, jer deca tu najviše imaju priliku da se igraju i istražuju, te ovo okruženje može biti najefikasnije i najprirodnije za podršku. Takođe, i činjenica da intervencije u predškolskim ustanovama mogu sprečiti socijalnu i vršnjačku isključenost koja često pogađa decu sa problematičnim ponašanjem podržava predškolsku ustanovu kao odgovarajuće okruženje za intervenciju. Većina dece provodi dosta vremena u predškolskoj ustanovi sa vaspitačima, koji postaju važni uzori i osobe od poverenja za decu. Shodno tome, vaspitači su odgovorni za pronalaženje načina kako da se najbolje nose sa situacijama i da pomognu deci koja imaju potrebu za podrškom u emocionalnom razvoju (Sjöman et al., 2016). 
Istraživanja pokazuju da intervencije koje se sprovode u predškolskim ustanovama imaju ukupan pozitivni razvojni ishod (Cheng, \& Ray, 2016). Međutim, ne postoji garancija da će se intervencije u predškolskoj ustanovi preneti u porodičnu sredinu.

\section{INTERVENCIJE USMERENE NA DECU I RODITELJE}

Uključivanje porodice, roditelja ili staratelja u procese intervencije je veoma važno i ima blagotvoran uticaj na razvoj deteta (Bratton et al., 2013). Ovi faktori mogu dati informacije o poreklu ponašanja deteta i stoga su korisne za planiranje efikasne intervencije.

Poseban pristup u okviru terapije igrom predviđa uključivanje porodice. Reč je o Filijal terapiji (Filial Therapy). Filijal terapija je itegrativni pristup koji proizlazi iz nekoliko različitih teorijskih orijentacija uključujući humanističke, interpersonalne, razvojne i socijalno-kognitivne teorije (Topham, \& VanFleet, 2011).

Ciljevi Filijalne terapije povezani su sa detetom: učenje prepoznavanja, prihvatanja i izražavanja emocija u potpunosti; povećanje samopouzdanja i samopoštovanja; razvoj strategija i veština efikasnog rešavanje problema; smanjivanje ili eliminisanje poremećaja u ponašanju i agresivnog ponašanja; razvoj prosocijalnog ponašanja. U pogledu ukupnih porodičnih odnosa, ciljevi filijalne terapije su: povećati poverenje dece $\mathrm{u}$ svoje roditelje; podsticanje roditeljske topline i prihvatanja njihove dece; za roditelje u porodicama sa dva roditelja podsticati rad u timu kao efikasniji; i, generalno, podsticanje prihvatanja kohezivne porodične klime koja podstiče zdrav razvoj dece (VanFleet et al, 2010). U idealnom slučaju, svi primarni staratelji učestvuju u sesijama za igru sa decom. Ovo povećava uticaj filijalne 
terapije u pomaganju porodicama da zamene negativne porodične obrasce sa onima koje su produktivniji i koji promovišu zdrav razvoj deteta.

Kao i većina veština i strategija, regulisanje emocija razvija se u prvih pet godina života. $\mathrm{S}$ obzirom da je to period kada deca veliki deo vremena provode u vrtićima, nemoguće je zaobići odgovornost predškolskih ustanova u sprovođenju naučno utemeljenih preventivnih programa. Predškolska ustanova je važan promoter zdravog i pozitivnog razvoja dece. Mnogi univerzalni preventivni programi u predškolskim i školskim ustanovama usmereni su na razvoj socio-emocionalnih kompetencija dece.

Primer ovakvog programa je Integralna metoda koja je implementirana u 9 predškolskih ustanova u Hrvatskoj. Cilj ove metode jeste podsticanje socio-emocionalnih kompetencija i prevencija poremećaja $u$ ponašanju. U skladu sa ciljem, definisane su socio-emocionalne veštine, kontekst vrtića kao uslov za razvoj prosocijalnog ponašanja, kao i programske aktivnosti predviđenje za uočavanje i uvežbavanje socioemocionalnih kompetencija koje su se odnosile kako na decu, tako i na roditelje i kontekst vrtića uopšte. Integralna metoda je u Hrvatskoj shvaćena kao pogodna za promovisanje socio-emocionalnih kompetencija, metoda za uspešnu komunikaciju sa roditeljima i njihovu edukaciju za kvalitetno roditeljstvo, ali i kao metoda za razvoj vrtića kao mesta zadovoljavanja potreba i dobrobiti svih (dece i odraslih) (Bašić, 2012).

\section{ZAKLJUČAK}

S obzirom da socio-emocionalni problemi i problemi u ponašanju predškoske dece predstavljaju značajnu dispoziciju za ozbiljne oblike 
rizičnog ponašanja u kasnijoj životnoj dobi, veoma je važno razvijati i sprovoditi rane preventivne intervencije.

Pre svega, ključni korak za razvoj uspešnih programa intervencije jeste identifikacija ranih faktora rizika za razvoj socio-emocionalnih problema i problema u ponašanju. Identifikacija rizičnih faktora usmerava fokus intervencije prema određenoj ciljnoj grupi. Poznato nam je da rizični faktori mogu da proizilaze od roditelja/porodice ili pak šireg okruženja. Iz tog razloga, važni su nam različiti pristupi i mogućnosti koje pruža rana intervencija.

Ipak, ukoliko prihvatamo multikauzalnost socio-emocionalnih problema i problema u ponašanju, kao i da većina dece koja imaju ove probleme dolaze iz porodica sa višestrukim rizikom, smatramo da su najdelotvorniji oni programi intervencije koji od toga i polaze. Pa tako, u odnosu na programe za roditelje čiji značaj svakako ne potcenjujemo i intervencije usmerene na decu, dajemo prednost programima intervencije koji su usmereni na decu i roditelje. Ukoliko dete već ispoljava određene socioemocionalne probleme i probleme u ponašanju, možemo zaključiti da nije dovoljno osnažiti same roditelje, već je neophodno da i dete ima mogućnost da na zdrav i njemu prikladan način radi na sebi i aktivno učestvuje u svom razvoju - a najpogodniji način za to je igra. Takođe, programi intervencije koji su usmereni samo na dete zanemaruju uglavnom ključne faktore rizika, a to su, naravno, roditelji (porodica). $\mathrm{S}$ druge strane, programi intervencije usmereni na decu i roditelje ne samo da su fokusirani na podršku i osnaživanje i jednih i drugih, već pružaju mogućnost izgradnje zdravog odnosa na relaciji roditelj - dete. 
Dakle, s obzirom da su socio-emocionalni problemi i problemi u ponašanju dece predškolskog uzrasta sve češći i da su najefikasniji oni programi prevencije i intervencije koji se sprovode na ranom uzrastu, neophodno je da praktičari koji rade u različitim institucijama zdravstvene i socijalne zaštite, ali oni u okviru vaspitno-obrazovnog sistema i koji se sa ovim izazovima susreću, već tokom inicijalnog obrazovanja razvijaju kompetencije za pružanje podrške deci i roditeljima sa kombinovanim faktorima rizika.

\section{SOCIO-EMOTIONAL PROBLEMS AND BEHAVIORAL PROBLEMS IN PRESCHOOL CHILDREN AND POSSIBILITIES FOR THE INTERVENTION}

\section{Abstract}

The number of children with social and emotional difficulties is constantly increasing. Socio-emotional problems and behavioral problems may pose a risk for serious disorders in later life. In addition, children with behavioral problems and underdeveloped socio-emotional competences tend to be less involved in the peer interaction, and sometimes even excluded from social activities. Many children with basic socio-emotional problems and behavioral problems, and without formal diagnosis, such as e.g. disorders of the autistic spectrum, do not necessarily receive any help or intervention, while at the same time they represent a challenge that neither parents nor educators can bear. Children are at risk, and therefore it seems necessary to explore and understand which interventions are possible to support the social and emotional development of pre-school children. Preschool interventions can be focused on parents through various support, education and training programs, as well as on children in the form of various types of intervention based on the play, and also on parents and children.

Key words: interventions, child, socio-emotional problems, behavior problems. 


\section{REFERENCE}

Ashiabi, G. S. (2007). Play in the preschool classroom: Its socioemotional significance and the teacher's role in play. Early Childhood Education Journal, 35, 199 -207.

Bailey, R. (2002). Playing social chess: Children's play and social intelligence. Early Years, 22, 163-173.

Baker, B. L., McIntyre, L. L., Blancher, J., Crnic, K. A., Edelbrock, C., \& Low, C. (2003). Pre-school children with and without developmental delay: Behaviour problems and parenting stress over time. Journal of Intellectual and Developmental Disability, 47(4/5), 217-230.

Bašić, (2012). Socijalno-emocionalno učenje i prevencija rizičnih ponašanja u okruženju predškolskih ustanova. U: I. Pehlić, E. Vejo i A. Hasanagić (Ur.), Suvremeni tokovi u ranom odgoju, (pp. 495-511). Zenica: Islamski pedagoški fakultet Univerziteta u Zenici.

Bratton, S. C., Ceballos, P. L., Sheely-Moore, A. I., Meany-Walen, K., Pronchenko, Y., \& Jones, L. D. (2013). Head start early mental health intervention: Effects of child-centered play therapy on disruptive behaviors. International Journal of Play Therapy, 22(1), 28-42.

Bratton, S. C., Ray, D., Rhine, T., \& Jones, L. (2005). The Efficacy of Play Therapy With Children: A Meta-Analytic Review of Treatment Outcomes. (1). Professional Psychology: Research and Practice, 36(4), 376-390.

Campbell, S. B., Shaw, D. S., \& Gilliom, M. (2000). Early externalizing behavior problems: toddlers and preschoolers at risk for later maladjustment. Development and Psychopathology, 12(3), 467-488.

Caselman, T. D., \& Self, P. A. (2008). Assessment instruments for measuring young children's social-emotional behavioral development. Children \& Schools, 30(2), 103-115.

Carter, A. S., Briggs-Gowan, M. J., \& Davis, N. O. (2004). Assessment of young children's social-emotional development and psychopathology: Recent advances and recommendations for practice. Journal of Child Psychology and Psychiatry and Allied Disciplines, 45(1), 109-134. 
Cheng, Y.-J., \& Ray, D. C. (2016). Child-Centered Group Play Therapy: Impact on Social-Emotional Assets of Kindergarten Children. The Journal for Specialists in Group Work, 41(3), 209-237.

Claessens, A. (2012). Kindergarten child care experiences and child achievement and socioemotional skills. Early Childhood Research Quarterly, 27(3), 365-375.

De Graaf, I., Speetjens, P., Smit, F., de Wolff, M., \& Tavecchino, L. (2008). Effectiveness of The Triple $\mathrm{P}$ Positive Parenting Program on Behavioral Problems in Children. Behavior Modification, 32(5), 714735.

Denham, S. A., Blair, K. A., DeMulder, E., Levitas, J., Sawyer, K., Auerbach-Major, S., \& Queenan, P. (2003). Preschool emotional competence: pathway to social competence? Child Development, 74(1), 238-256.

Diken, I. H., \& Rutherford, R. B. (2005). First step to success early intervention program: A study of effectiveness with Native-American children. Education \& Treatment of Children, 28(4), 444-465.

Dodge, K. A., Lansford, J. E., Burks, V. S., Bates, J. E., Pettit, G. S., Fontaine, R., Price, J. M. (2003). Peer rejection and social information-processing factors in the development of aggressive behavior problems in children. Child Development, 74, 374-393.

Gardner, F., Shaw, D., Dishion, T., \& Burton, J. (2007). Randomized Prevention Trial for Early Conduct Problems: Effects on Proactive Parenting and Links to Toddler Disruptive Behavior. Journal of Family Psychology, 21(3), 398-406.

Jianghong, L. (2004). Childhood Externalizing Behavior: Theory and Implications. Journal of Child and Adolescent Psychiatrics Nursing, 17(3), 93-103.

Kariuki, M. W., Chepchieng, M. C., Mbugua, S. N., \& Ngumi, O. N. (2007). Effectiveness of Early Childhood Education Programme in Preparing Pre-School Children in Their Social-Emotional Competencies at the Entry to Primary One. Educational Research and Reviews, 2(2), 2631. 
Klemenović, J. (2014). Spremnost za školu u inkluzivnom kontekstu. Novi Sad: Filozofski fakultet u Novom Sadu.

Ladd, G. W. (2006). Peer rejection, aggressive or withdrawn behavior, and psychological maladjustment from ages 5 to 12 : an examination of four predictive models. Child Development, 77, 822-846.

Özyurt, G., Dinsever, Ç., Çaliskan, Z., \& Evgin D. (2018). Can positive parenting program (Triple $\mathrm{P}$ ) be useful to prevent child maltreatment? Indian Journal of Psychiatry, 60(3), 286-291.

Pešikan, Antić. (2012). Učenje i razvoj na ranim uzrastima. U: A. Baucal (Ur.), Standardi za razvoj i učenje dece ranih uzrasta u Srbiji (pp. 85111). Beograd: Institut za psihologiju Filozofskog fakulteta Univerziteta u Beogradu.

Ray, D. (2004). Supervision of Basic and Advanced Skills in Play Therapy. Journal of Professional Counseling, Practice Theory, \& Research, 32(2), 28-41.

Sanders, M.R., Markie-Dadds, C., Tully, L., \& Bor, B. (2000). The Triple P Positive Parenting Program: A comparison of enhanced, standard and self-directed behavioural family intervention for parents of children with early onset conduct problems. Journal of Consulting and Clinical Psychology, 68, 624-640.

Schmitt, S. A., Flay, B. R., \& Lewis, K. (2014). A Pilot Evaluation of the "Positive Action" Prekindergarten Lessons. Early Child Development and Care, 184(12), 1978-1991.

Shaw, D., \& Taraban, L. (2018). New Directions and Challenges in Preventing Conduct Problems in Early Childhood. Child Development Perspectives, 11(2), 85-89.

Sjöman, M., Granlund, M., \& Almqvist, L. (2016). Interaction processes as a mediating factor between children's externalized behaviour difficulties and engagement in preschool. Early Child Development and Care, 186(10), 1649-1663.

Tahirović, S. (2015). Moć igre u psihoterapijskom radu sa djecom. Unapređenje kvalitet života djece i mladih, 182-193.

Topham, G. L., \& VanFleet, R. (2011). Filial therapy: A structured and straightforward approach to including young children in family 
therapy. The Australian and New Zealand Journal of Family Therapy, 32(2), 144-158.

UNICEF (2014). A Systematic Review of Parenting Programmes for Young Children. New York: Unicef.

VanFleet, R., Sywulak, A. E., \& Caparosa Sniscak, C. (2010). Child-centered play therapy. New York: The Guildford Press.

Waliski, A. D., \& Carlson, L. A. (2008). Group Work with Preschool Children: Effect on Emotional Awareness and Behavior. Journal for Specialists in Group Work, 33(1), 3-21.

Žunić-Pavlović, V., i Kovačević-Lpojević, M. (2011). Prevalencija i razvoj poremećaja ponašanja u detinjstvu. Specijalna edukacija $i$ rehabilitacija, 10(4), 725-742. 
